821.163.41.09“17““ Дубровник https://doi.org/10.18485/msc.2018.47.2.ch11

Славко В. ПЕТАКОВИЋ

Универзитет у Београду

Филолошки факултет
Оригинални научни рад

Примљен: 25. 10. 2017.

Прихваћен: 27. 12. 2017.

\title{
САТИРИЧНИ СУТОН „ВРЕМЕНА ОД ПОКЛАДА”
}

\begin{abstract}
Политичко-историјским струјањима која су захватила Европу крајем XVIII века вишеструко су уздрмани ослонци на којима је почивала Дубровачка република. Ово време, обележено у Дубровнику напуштањем конзервативних политичких ставова, слабљењем сталешке одељености племства и грађана и урушавањем традиционалног културног модела, донело је и сахњење старих обичаја, међу којима су се дуговекошћу издвајале свечаности у „време од поклада”. У раду се, на примерима песништва Ђ. Ферића, М. Златарића и Џ. Растића, разматра како су песници XVIII века у сатиричној визури сагледавали замирање карневалске традиције, која је у ранијим столећима доприносила утврђивању културног идентитета Дубровника, док се у новим околностима извитоперавала и губила везу са изворним смислом.
\end{abstract}

Кључне речи: карневализација, дубровачка књижевност, сатира, осамнаести век.

У више наврата и на немалом броју места у литератури су разматране сваколике прилике које су током осамнаестог века, а нарочито у његовој другој половини, донеле корените промене - друштвене, политичке и културноистоијске - широм Европе. Осветљавана је свестрано и резонантност тих дешавања у Дубровнику, који је реаговао на подстицаје са стране, опирући се некима и прилагођавајући се другима у сагласју са специфичношћу свога амбијента. Генерално гледано, друга половина столећа у Граду била је обележена уздрмавањем и преиспитивањем социо-културних темеља на које је вековима била ослоњена држава изразито конзервативног устројства. Тешко је побројати сва збивања на макро и микро плану која су се пресудно рефлектовала на дубровачки миље, али се за ову прилику она могу сврсисходно и у крупној размери мапирати, узимајући као оријентациона чворишта унутрашњи раздор племства (бивши грађани постају „нови” племићи; „стари” се конфронтирају међусобно због различитих политичких оријентација), еко-

"petakovics@yahoo.com 
номско пропадање аристократије и богаћење грађања, све снажнији француски, потом и аустријски утицај у култури и политици и др.

Збивања у свакодневици су одјека имала у књижевности, посебно сатиричној, која је изразито негована у другој половини осамнаестог века (Бојовић 2014: 463). Аутори, обдарени карактеристичним смислом за хумор и сатиру - који је, изгледа, нарочито красио Дубровчане, специфичном осетљивошћу су реаговали на промену друштвених дамара Града. Ношени бујном инспирацијом, сатиричари су се усредсређивали на парадигматичне примере преобликовања - најконзервативнији међу њима сматрали су: грубог изневеравања - традиционалних обичаја и реда ствари на који су навикли. Међу најстарије друштвене обрасце који су чврсто уграђени у културолошки идентитет Дубровчана, спадало је одржавање карневалских свечаности. Карневал је у Дубровнику, попут других средина диљем Медитерана, доживео промене током столећа од ритуално-обредне до ритуално-забављачке форме, уз стално присуство политичке димензије (Јанековић Ромер 2003: 34). На промене у карневалским светковинама утицао је, између осталог, развој дубровачких институција, па је на пример, од друге половине седамнаестог века (1682), устаљивање места извођења представа у позоришној згради (Пантић 1952: 44-45) донело новину у покладној традицији. ${ }^{1}$

Институционализовање театра у Дубровнику, међутим, уместо да допринесе уређивању друштвеног понашања, донело је својеврсну пометњу у покладне дане. Она је била узрокована непомирљивошћу социјалних група које су се у карневалско време током извођења позоришних представа налазиле сучељене у ограниченом простору. Почетку глумачке игре претходила је својеврсна представа у публици. Може се на основу архивских података донекле реконструисати амбијент дубровачког позоришта. Неред је настајао због свађа послуге одаслате да резервише места за господаре јер је боље позиционирање у гледалишту имало осим практичне функције, и симболичко значење. Долазило је до сукоба - псовања и туча - међу племством које је своје првенство у политичком животу потврђивало правом на најбоља места у позоришту. „Стари” племићи жилаво су бранили недодирљивост свога достојанства, док су „нови” успон у социјалној хијерархији и равноправност са „старим” (в. о томе Ћосић, Векарић 2001; 2005) желели да „огласе” у јавности освајањем седишта са најбољим погледом на позорницу. Неки су се пробијали на позорницу заузимајући места за седење међу члановима оркестра. Општу конфузију је појачавала појава маскираних и наоружаних гледалаца који су се, налазећи лако повода у општој вреви, разрачунавали са опонентнима. Грађани су се у складу са својим могућностима, уистину са дубином и набијеношћу кеса плодовима трговачког предузетништва, гурали

\footnotetext{
1 Зграда државног арсенала, тзв. „Орсан”, од 1682. године до свог уништења у пожару 1817. године, служила је као позоришна дворана. Унутрашњост Орсана 1682. године скромно је реновирана и прилагођена потребама позоришне публике тако што је поред ограђене ложе за дубровачке владике подигнута још једна за угледне пучанке из редова антунина (Пантић 1952: 44-46). Током осамнаестог века дубровачка власт је настојала да прописима регулише понашање у позоришту, па су посебним одлукама прецизно одређивана места за седење гледалаца у зависности од њихове сталешке припадности (Беритић 1953: 329-357).
} 
међу аристократију показујући да критеријум „чистоте крви” није више тако непробојна баријера при уздизању на друштвеним лествицама. Шароликост призора употпуњавао је долазак госпођа, чије носиљке су, раскошно украшене у мери коју је богатство власнице допуштало, стварале гужву затварајући улаз у позориште. Да се све ово дешавало у дубровачком позоришту сазнајемо посредно, на основу докумената у којима су детаљно и таксативно разрађени прописи којима се санкционише недозвољено понашање у театру (Беритић 1953: 332). Ипак, начином понашања у позоришту Дубровчани нису одударали чак ни од житеља далеко већих урбаних средина. У Венецији су, на пример, сукоби међу гледаоцима били врло брутални и имали су крваве епилоге (Деановић 1931: 299).

Могло би се рећи да је Дубровник у покладне дане живео театар у театру. Та појава пружала је прворазредну мотивско-тематску грађу домаћим сатиричарима. Древна метафора „света као позорнице” (Курцијус 1996: 232-242), имала је особену, инвертовану, поетску интерпретацију у песмама Ђура Ферића (Carnovalis ragusini descriptio macaronica), Марина Златарића (Вечер и ноћ у Дубровнику) и Џона Растића (Bacchanalia), у којима је приказивана „позорница као свет”. ${ }^{2}$ Представа позоришта један је од основних конструктивних елемента песничке концепције pars pro toto у приказивању друштвене стварности у песмама дубровачких стваралаца, у којима се слика позоришта јавља као парадигма извитоперења друштвених вредности. Различитост песничке визуре, пак, узрокована је сталешком припадношћу и идеолошким опредељењем песника. Ферић је био свештеник, Златарић потомак „нових” племића, ${ }^{3}$ а Растић горди изданак „старе” аристократије. За разлику од Златарића, чија припадност „новом” племству је укидала могућност да сатирички пева о оштрој разлици између прошлости и садашњости - јер је садашњост искључива категорија у оквиру које „нови” племићи утврђују свој легитимитет у дубровачком друштву - и Ферић као свештеник, а нарочито староколеновић Растић, сатирично-иронично су тонирали своје песничке слике, заснивајући их на снажном наглашавању темпорално-културолошке опозиције некад : сад. Њихова песничка слика дубровачких поклада крајем осамнаестог века има, дакле, социјално-идеолошку и политичку димензију, док је Златарићева лишена те значењске дубине и ограничена на комичносатиричну представу некултивисаног понашања суграђана.

Мотивација Ђура Ферића за Макаронски опис дубровачких поклада назире се у уводу Ad legitores, у коме аутор истиче да је уложивши много напора у штампање својих Парафраза псалама и Фабула 4 био изневерен. Намера

${ }^{2}$ Стихове наводимо према следећим изворима: Ђ. Ферић и Џ. Растић - Hrvatski latinisti: pisci 17-19. stoljeća, II, PSHK, 3, MH, Zagreb, 1969; Latinsko pjesništvo u Hrvata, prir. V. Vratović, Zagreb: Školske novine, 1997; М. Златарић - С. Петаковић, Марин Златарић дубровачки песник XVIII века, Београд: Филолошки факултет, 2015.

${ }^{3}$ Ферић је био пучанин, а Златарић најпре доминиканац, потом световни свештеник, али ове чињенице примарно нису утицале на њихов идеолошки хоризонт.

${ }^{4}$ Односи се на дела Paraphrasis psalmorum роеtica (1791) и Fabulae ab Illyricis adagiis desumptae (1794) - што посредно указује да је песма Carnovalis ragusini descriptio macaronica настала у последњим годинама осамнаестог века. 
му је била да делима утиче на верско и морално васпитање Дубровчана, али су они, оглушивши се о племенитост његовог подухвата, купили мали број примерака књига, чије штампање је било скупо. Зато је по узору на Мерлина Кокаија (Теофила Фоленга) и других песника на макаронском језику, одлучио да пева о лакшим темама, не би ли посредно заинтересовао Дубровчане и за своја озбиљнија дела. Мада би се на основу Ферићевог увода рекло да је он експлицитно указао на поетичке основе своје песме (узор Фоленго, утилитарно-дидактична и забавна намена), ипак се мотивација назире јер аутор није отворено указао на неколико елемената важних за потпуно разумевање Макаронског описа дубровачких поклада. Наиме, разочаран због слабе продаје Парафраза и Фабула, он је одлучио да се сатирички разрачуна са средином чији ниски културни ниво је допринео неприхватању његових „озбиљних" дела. Због тога би се у обзир могао узети и Ферићев лични однос према друштвеној средини чије мане сатирично критикује. Не треба занемарити да Ферић из специфичне позиције, као неолатиниста, тј. баштиник одређене културолошке и постичко-стилске парадигме, критички посматра народну карневалску светковину. Опредељујући се за макаронски, латинско-италијанску језичку мешавину, нагласио је уметничку везу са Фоленговим стилским обрасцем, као и са специфичном струјом италијанског сатиричног песништва. Ипак, ова књижевноисторијска релација могла би се дијахроно и синхроно проширити и на домаћи и европски књижевни оквир. На основу језичког медија и тополошког регистра може се Ферићева поезија довести у везу и са старијом књижевном баштином. Појам „макаронски” језик, означавајући језичко-стилски конгломерат латинског и италијанског језика, настао спајањем латинске морфологије и граматике са италијанском лексиком и синтаксом (Ферони 2005: 315), повезује се искључиво са италијанским песништвом. Међутим, мешање различитих језика и језичких регистара зарад постизања комичног, ироничног и сатиричног ефекта, конвенционалан је стилски топос. Међу првима је још римски сатиричар Луцилије, потом Варон, Јувенал и др., певао мешајући латински са грчким. У Луцилијевој сатири била је успостављена и опозиција некад : сад, којом се наглашавао степен девијације савремености у односу на прошлост. У светлу оваквог поимања ствари, Ферићево стваралаштво припада богатој традицији европског песништва, од антике на овамо, обележног одређеним поетичко-стилским и језичким регистром. Такође, Ферићеву, али и Златарићеву и Растићеву, сатиру одликује континуитет са Хорацијевом сатиром, ${ }^{5}$ али и са посебним типом сатире - мениповском сатиром, у којој се о озбиљним темама пева на шаљив начин, и која је „postala jedan od glavnih nosilaca i prenosilaca karnevalskog osećanja u literaturi” (Бахтин 1967: 176). Карневалски дух мениповске сатире још један је слој који трасира релацију Ферићеве песме са Фоленговим стваралаштвом. Сатирични опус Ђура Ферића, и поред тога што је заснован на хибридном споју латинског и италијанског, могао би се разматрати и у склопу домаће песничке традиције, утемељене на локалној „макаронској”

\footnotetext{
${ }^{5}$ Хорације: ,[...] ridiculum acri / fortius et melius magnas plerumque secat res” (Сатира I, 10).
} 
варијанти - мешавини народног и италијанског језика, на којој су у седамнаестом веку певали један од Мажибрадића - Мароје или Хорације (Кастропил 1953: 239), Паскоје Примовић, Џоно Палмотић, а у наредном столећу Антун Глеђевић, Марин Златарић и други дубровачки песници.

Осим овога, стилске и мотивско-тематске карактеристике Златарићеве и Растићеве песма сведоче о поетичком континуитету између дубровачког, класичног и италијанског песништва. Композиција и стил Златарићевог троделног поетског триптиха (,Јутро дубровачко, Објед и п’објед у Дубровнику, Вечер и ноћ у Дубровнику”) унутар кога се јавља сатирична слика дубровачког театра упућују на одређено узорно извориште, тј. указују да је дело Ђузепеа Паринија (Il Giorno) било један од главних извора инспирације Златарићу (Петаковић 2015: 126-128). Идеолошки најконзервативнији и најоштрији у сатири, био је Растић, на шта указује и наслов „Баханалије”, његове песме посвећене дубровачком карневалу. У литератури је давно истакнуто Растићево језичко, стилско и поетичко угледање на Хорација (Шрепел 1893: 147), што је унеколико релативизовано уочавањем полемичког односа дубровачког песника према римском, уз истицање Јувеналовог стваралачаког наслеђа у Растићевој сатири (Јовановић 1997: 291-305). Све ово показује да су дубровачки сатиричари припадали дуговекој традицији сатиричног песништва угледајући се на најзначајније представнике ове врсте у светским размерама.

У Ферићевим, Златарићевим и Растићевим сликама карневалске свечаности доминира представа општег нереда и несклада. Сатиричну визуру одликује наглашена гротескна стилизација, у чијој основи су симултаност и противречност. Песници - у највећој мери Ферић и Растић - успостављају симултани поглед на објекат (збивања на позорници и понашање публике) и субјекат (свој доживљај позоришта) наглашавајући противречност између њих. Реакција публике на збивања у театру снажно одудара од реакције песника-посматрача/моралног арбитра и величина тог раскорака илуструје степен друштвене девијације која се упризорује. У Ферићевој песми се конвенционално наглашава опрека прошлост : садашњост уз истицање дуговеке традиције одржавања карневалских свечаности: „Би ли прошла и једна година а да се пред бројним народном није приказивала комедија и да на тргу није плесало силно мноштво младежи!”” (Ови стихови евоцирају исказе из пролога Држићевог Дунда Мароја о „времену од поклада” које је „од старијех нашијех одлучено на танце, игре и весеље” - сведочећи о трајности карневалске светковине у Дубровнику.) Наглим прелазом (,,а сад чуј како је код нас") наглашава се свест о дубоком раздору диспаратних категорија накад : сад, којима се упућује на сукоб прошлости и савремености као одређених културолошких парадигми. Оштро Ферић указује да од данашњих маски нема „ничег неукуснијег”, сегментирајући призор у две секвенце којим обухвата понашање пучана и грађана. Пучани се преоблаче у „ловце попут

\footnotetext{
${ }^{6}$ Утемељење права на препуштање карневалском расположењу Ферић налази у литерарно-филозофском ауторитету Хорацијевих стихова „Dulce est desipere in loco” (Carmina IV, 12, 28).
} 
Влаха” и „набијају пушке мекињама или пиловином” гађајући пролазнике, или „по сељачком обичају, уз дипле и свирале, воде младенку”. Други се маскирају у трговце, слушкиње или онако - иронично резимира Ферић - „како их упућује властита распуштеност или кукавни проналазак њихове главе”. Нису бољи ни „финији грађани” јер опонашају „модерну високу фризуру госпођа” подижући „косу увис као цилиндар”, глуме гимназијске наставнике шибајући децу и недолично се понашајући. Нескладу доприноси појава оних који никада у позоришту нису видели Доктора, Пулчинелу, Бригелу ни Арлекина, а усуђују се да играју њихове улоге. У Ферићевим стиховима запретена је и фина референца која употпуњује слику позоришних збивања у Дубровнику. Упозоравајући резигнирано „крабуље” да ће им судбина бити невесела „ако година добро уроди наранчама” песник указује на могућу реакцију незадовољне публике која је гађањем трулим воћем кажњавала извођаче због својих изневерених очекивања.

Специфичном алегоризацијом, попут Јувенала који симболичким именима упућује на места и личности (Шрепел 1894: 68, 104), Растић критикује Квирићане, тј. Дубровчане, и „забаву квиритску ову годишњу”. Затим, слично Ферићу, уверава читаоца у истинитост сопствене песничке визуре, позиционирајући се као учесник и сведок карневалске светковине у позоришту. Сугестивно дочарава како скинувши тогу и стављајући маску на лице улази, „у стилу уходе која се кришом шуња”, у позориште. Непримереност извођача и њихових улога запажа се на сваком кораку, а карневалска иконографија служи само да прикрије лица обесних учесника који под њом бесрамно иживљавају слободу - „маска је прекрила лице, а сваки однијела зазор". Физичко маскирање спољашња је манифестација суштинског, духовног лакрдијашког прерушавања. Слушкиње рецитују песме које страни песник „написа њима на језику нашем”. Гротескна дисторзија снажно одјекује јер песме „саме се са собом не слажу нити метром, нити смислом”. И старије госпође, понете карневалском атмосфером, заборављају на достојанство па се, губећи меру у понашању, гурају међу омладину - „гура се баба међу плесачице, зрелија сама за крематориј, вреднија огња погребне ломаче но да се бави огњем Венере”. Жустру борбу за боља места у публици - бележи и Ферић - а сугестивно-комично („Ке лудости, ка sciochezza”) фиксира Златарић („Кад јој драга није сусједа, / граби мјесто, фацом пријети”).

Ни мушкарци не дају бољи пример понашања. Нестрпљивост племића у сусрету са противницима долази до изражаја, те се види од партера до ложа („из платее до палкета”) како „када од феле нијесу equale / плећи обphy a proprii pari”. Динамичним повезивањем одељених елемената - озбиљног (традиционална представа о позоришту као храму културе) и комичног (понашање публике) формира се гротескно-реалистична слика, обележена свођењем апстрактног на материјално-телесни план (Бахтин 1978: 28). Када је борба за место окончана, открива се у потпуности лажност и испразност жеђи градских дама за културним догађајима. Беспоштедне у надметању за место у публици, бивају оковане досадом када представа почне: „Толико ура тужна сједи / ко кокоши у капунари, / румени се, мори и блиједи”. Моното- 
нију ублажавају свакојако („Ал’ ти жмуо, ал’ кафа, / ваља черто пробавити”), не зазирући од кршења конвенција друштвеног понашања у театру јер оне у Дубровнику и не постоје. ${ }^{7}$ Из нешто другачије перспективе Растић дочарава театарску публику. Иронично-сатирично коментарише појаву карневалског фамилијарног контакта међу гледаоцима. Истиче Растић да међу гледаоцима нема сталешког раздвајања нити нелагоде због тога - што је скандалозно за песника. Хрлећи на представу, гледаоци заузимају седишта без икаквог реда - „према патрицијкама иде да сједне кћи некаква кухара”, само ходници одељују бријаче од лекара, „своднике и слуге од проститутке”. Општа разузданост захвата и изједначава све, те се посматрач једва уздржава од грохота видећи ,[...] како се конзул и накупац прженог грашка / радују истом радошћу, истом се диве, те исто / хоће, а исто неће".

Изоштреност слике у Ферићевој и Растићевој песми на месту где се дубоко иронично приказује непримерено присуство сводника и проститутки у позоришту евоцира карактеристичан пасаж из Јувеналове треће сатире. Римски сатиричар је дочаравајући атмосферу у позоришту саркастично певао о местима која су у публици резервисана за „sinove svodnika” чије место poђења, „kupleraj”, и „tovqene potomke” (Јувенал 2009: 145) из тајних веза госпођа из виших кругова и гладијатора. Осим овога, Јувенал помиње долазак „lakrdijaša” на бину чији „vrisak” уплаши „seosko dete” у публици које се „krije majci u nedra od straha”. Такође, указује горко на непостојање разлике између племенитих Римљана и простог пука - „svi su obučeni jednako”, „ovde svak mora da šljašti, da dobrano pređe svoj / guber" (Јувенал 2009: 145). Мотивска сличност наговештава - што до сада у литератури није аргументовано овим примером - на могућност постајања поетичке трасе између Јувеналове и Растићеве сатире.

Са много детаља Растић показује у којој мери одударају стварна дешавања у позоришту од намене храма богиње Талије. Помиње „мајке и снахе” распоређене на седиштима које уместо отпочињања представе нестрпљиво очекују долазак љубавника с којим за трен успостављају комуникацију дискретним, тајним знаковима - „очицама, шеширом, лепезама и ногом”. Атмосфера у дубровачком позоришту конкретизована је натуралистичким детаљима - театар се приказује као место „претамно и нечисто” одакле „ти удара у нос веома гадан смрад, достојан подземног свијета". Најдубље гнушање према извитопереној карневалској свечаности исказано је иронијом набијеним реторским питањем фиктивном сабеседнику - како може да се „фино окрепљује” док трпи оно „што би хтјела једва подносити проститутка у смрдљивим крчмама". Призор оркестра - састављеног од једва половине потребних чланова - и музике која наликује ковачевом стругању по металу, не обесхрабрује публику јер она овацијама испраћа наступ „уметника”. Није

\footnotetext{
${ }^{7}$ Када би се стихија у публици смирила и представа почела, Дубровчани су је пратили у атмосфери далекој од сваке конвенционалности. Са одмицањем глумачке игре, публика је бивала све лежернија, па „[...] kad je predstava poduga bila, čeljad su se u ložama zalagala jelom, da se malo prihvate; ta su jela obično bila 'kotonjata', 'mantala' i neizostavni 'beškotini' (slatki dvopeci)" (Берca 1941: 144).
} 
то ни чудо, заједљиво песник резимира виђено, кад у публици већина „има уши попут краља Миде” и разуме се у уметност колико и „магарац у лиру”. Од наступа музичара не одудара ни игра глумаца. Комади који се изводе на сцени немају вредности и делују као да их је „лакрдијаш с јавне цесте саставио”, док глумац „неопраних уста” говори делујући у комедијама грубо и неспретно као „месар који би се опасао војничким мачем”. Ово не изненађује јер се онај који се до мало час „крио у гнусу тамне крчме гдје је масном сланином пунио кобасице” обрео на позорници и одједном постао горди глумац што очекује аплауз публике. ${ }^{8}$

Навођењем реалија из натуралистичког регистра успоставља се још рељефнија слика гротескног позоришта. Ферић помиње топлу текућину која се као киша пробија кроз дрвену конструкцију галерије (,„[...] pluviam sentire sereno, / Per fendituras ligni quae calda trapassat” - Пуратић 1975: 51). Златарић евоцира необичну театарску догодовштину приликом које је „настрадао” извесни глумац: „спомињем се кад с палкета / тужна Криста речитани / окропи га certa acquetta”. И Растић пева о сличном искуству: „Некаква ме роса однекуд овлажи те ми страда огртач и тога. Како гнусна киша капа одозгор!”

Песничка слика, уобличена у гротескно-реалистичном стилском регистру, имала је, вероватно, упориште у стварности. ${ }^{9}$ Но, она у литерарном оквиру указује на специфичну интерпретацију карневалске игре, лакрдијашког крунисања и детронизације карневалског краља. Глумац, чија појава је иронично маркирана одредницама „тужан” и „речитани”, и који би требало да буде главна фигура у театру, бива грубо детронизован традиционалним гестом унижавања (Бахтин 1978: 163). Топографско-симболичка инверзија горе : доле (глумац/уметност : унеређена жртва) иронизована је посебном лексичком еквилибристиком јер се текућина са балкона - чије порекло се назире у Растићевом дочаравању „гнусне кише” - помиње деминутивним обликом „acqueta” (водица). Инверзија на топографско-симболичном плану назначена је и у ширем контексту бизарном компарацијом позоришта са „смрдљивом крчмом”, „претамним и нечистим” подземљем, при чему је други сегмент поредбеног комплекса вредносно супериоран у односу на први. На овом месту песничка визија карневалског „живота окренутог наопачке” досеже највеће дубине, у којима бистрину сатиричног смеха тамни тешка резигнација.

Поетски рефлекс друштвена стварност је имала у сатири, заснованој на књижевној традицији карневализације (Бахтин 1967: 196), из које су наслеђе-

\footnotetext{
${ }^{8}$ Не би се пак, истиче песник, са̂м ругао укусу публике када би у циркусу посматрала представу са животињама, али пошто гледаоци упорно тврде да им је лепо и духовито оно што приказује „lakrdijaš neopranih ruku” и када је за њих мајмун исто што и човек, онда мора сатиром „zabludama pokazati pravu sliku”. Тиме се јасно указује да мета Растићеве сатире није само нижи друштвени сталеж који с презиром старог аристократе посматра, већ и опште пропадање друштвених вредности, а нарочито „vulgarizacija i profanacija” уметности (Посавец 1982: 272).

${ }^{9}$ Уживање гледалаца бивало је накратко помућено изненадним инцидентима, проузрокованим потребама и навикама сваковрсне публике. Догађало се да „[...] sa stropa od galerije nekakva tekućina curi i poštrapa te", али ни то није изазивало велико чуђење будући да је било уобичајено да „ро koja žena dovela sobom svoje napršče” (Берса 1941: 107).
} 
ни карактеристични елементи: фамилијаризација, профанација, лакрдијашко прерушавање, „крунисање” и „детронизација” - у склопу стилског комплекса гротескне реалистичности. Тај поетски арсенал употребљен је како би што сугестивније Ферић, Златарић и Растић исказали сложени колоплет осећања - очајање, подсмех, сету, одбојност због уверења да је дубровачко друштво карневализовано и да је стихија захватила све слојеве живота. Ако се узме у обзир да су извори позоришта „у друштвеној драми” и да позориште, представља у извесном виду „тумачење и објашњење живота” (Тарнер 1989: 17, 21), знаковите, између осталог, бивају песничке представе о дубровачком позоришту и позоришном животу у осамнаестом веку када се социјална и културна „драма” у Граду ближила кулминацији. Тада је театар у Граду имао специфична обележја јер је двоструко рефлектовао стварност - уметнички у позоришној представи и социолошки у публици.

Зато иронично-сатирична представа позоришта, стилизована моделом лакрдијашког прерушавања, прераста у метафору друштвеног стања. Испоставља се да су сви у театру (глумци, оркестар, публика) - симболично: и у стварности - лакрдијашко-гротескни дублети онога што привидно истински отелотворавају. Узвишено је расточено у приземном и грубо-материјалном; профанисана је сакралност позоришта и оскрнављена традиција карневала, древног „времена од поклада”. Свакодневица је, очито показују покладе и позориште, изглобљена из нормалног поретка јер карневал и театар номинално јесу али традицијски нису дубровачки, тачније - „обрнути свет” није само привремена симулација правог света, већ постојана гротескна перспектива.

\section{ЛИТЕРАТУРА}

Бахтин 1967: M. Bahtin, Problemi poetike Dostojevskog, Beograd: Nolit.

Бахтин 1978: M. Bahtin, Stvaralaštvo Fransoa Rablea i narodna kultura srednjeg veka i renesanse, Beograd: Nolit.

Беритић 1953: N. Beritić, Iz povijesti kazališne i muzičke umjetnosti u Dubrovniku, Dubrovnik: Anali Historijskog instituta JAZU u Dubrovniku, 329-357.

Бepca 1941: J. Bersa, Dubrovačke slike i prilike, Zagreb: Matica hrvatska.

Бојовић 2014: 3. Бојовић, Историја дубровачке књижевности, Београд: СКЗ.

Деановић 1931: M. Deanović, Talijanski teatar u Dubrovniku XVIII vijeka, Dubrovnik: Rešetarov zbornik iz dubrovačke prošlosti, 289-308.

Јанековић Ромер 2003: Z. Janeković-Römer, Nasilje zakona: gradska vlast i privatni život u kasnosrednjovjekovnom i ranonovovjekovnom Dubrovniku, Dubrovnik: Anali Zavoda za povijesne znanosti HAZU u Dubrovniku, 41, 9-44.

Јовановић 1997: N. Jovanović, Rastić čita satire, Split: Dani Hvarskoga kazališta: Građa i rasprave o hrvatskoj književnosti i kazalištu, 230, 1, 291-305.

Јувенал 2009: Decim Junije Juvenal, Satire, Beograd: Fedon. 
Кастропил 1953: S. Kastropil, O jednom zborniku dubrovačke lirike, Zagreb: Građa za povijest književnosti hrvatske, 24, 237-264.

Курцијус 1996: Е. Р. Курцијус, Европска књижевност и латински средњи век, Београд: СКЗ.

Пантић 1952: М. Пантић, Архивске вести о дубровачком позоришту друге половине XVII века, Београд: Зборник радова САH, XVII, 2, 39-60.

Петаковић 2015: С. Петаковић, Марин Златарић дубровачки песник XVIII века, Београд: Филолошки факултет.

Посавец 1982: Z. Posavec, Estetika romantičnog klasicizma u Dubrovniku, Dubrovnik: Anali Zavoda za povijesne znanosti Istraživačkoc centra JAZU u Dubrovniku, XIX-XX, 263-288.

Пуратић 1978: Ž. Puratić, Bilješke uz makaronsku poeziju i djelo „Epigrammata de nostratibus" Đorđa Ferića, Zagreb: Latina et Graeca, 3, 4, 47-57.

Тарнер 1989: V. Turner, Od rituala do teatra: ozbiljnost ljudske igre, Zagreb: August Cesarec.

Чосић, Векарић 2001: S. Ćosić, N. Vekarić, Raskol dubrovačkog patricijata, Dubrovnik: Anali Zavoda za povijesne znanosti HAZU u Dubrovniku, XXXIX, 305-379.

Чосић, Векарић 2005: S. Ćosić, N. Vekarić, Dubrovačka vlastela između roda i države: salamankezi i sorbonezi, Zagreb-Dubrovnik: HAZU-Zavod za povijesne znanosti u Dubrovniku.

Ферони 2005: Đ. Feroni, Istorija italijankse književnosti, I-II, Podgorica: CID.

Шрепел 1893: M. Šrepel, O latinskoj poeziji Junia Restija, Zagreb: Rad JAZU, XXXVII, 99-158.

Шрепел 1894: M. Šrepel, Rimska satira, Zagreb: Matica hrvatska.

Slavko V. Petaković

THE SATIRIC TWILIGHT OF "CARNIVAL TIME”

(Summary)

Certain poems by Đ. Ferić, M. Zlatarić and Dž. Rastić, which thematise the carnival life of the Ragusans, establish a carnivalised, ironic-satiric idea of the theatre. Stylised through a model of farcical disguise, the vision of the theatre grew into a metaphor of the social state. Showing the sublime crumbling in the low phenomena, along with the profaned sacrality of the theatre, the Ragusan poets pointed to the phenomenon of the "inverted world", where reality is out of joint of the normal order. They demonstrated that the "new", i.e. "inverted world" was founded, among other things, on the simulation (through a grotesque replica of festival ritual and theatrical life) of continuity with the traditional values of Ragusan culture. 